\title{
Do Keiretsu Really Hinder FDI into Japanese Manufacturing?
}

\section{Satomi Kimino ${ }^{\mathrm{a}}$, Nigel Driffield ${ }^{\mathrm{b}}$ and David Saal $^{\mathrm{b}}$}

a Centre for Leadership Studies,
University of Exeter Business School,
Rennes Drive,
Exeter

UK EX4 4ST

${ }^{\mathrm{b}}$ Economics and Strategy Group,

Aston Business School,

Aston University,

UK B4 7ET

\begin{abstract}
This paper examines an issue that has received considerable comment but little analysis. It has often been argued that the presence of the Keiretsu in Japan has been instrumental in deterring multinational firms from entering Japan, though evidence for this is patchy. We present some new analysis of this issue, thereby evaluating the effects of Keiretsu on inward investment penetration in Japan. In contrast to previous work in this area, our results suggest that there is little relationship between inward FDI and keiretsu networks, once one controls for endogeneity and unobservable heterogeneity. In contrast, the results do illustrate some important interaction effects between Keiretsu and other explanatory variables that explain differences in inward investment penetration.
\end{abstract}

Keywords: Keiretsu, FDI, market structure.

JEL: F23, L60 L41 


\section{Introduction}

The purpose of this paper is to examine whether the networks of horizontal and vertical Keiretsu linkages influence the decision for foreign firms entering the Japanese market. While most theoretical developments in this area tend to focus on the role of the inward investor as a dominant player within the host country, Japan presents a rather different and underresearched case. Japan’s network of interlocking Keiretsu suggest that for much of Japan’s post war history there existed a set of local firms with equal financial and technological muscle relative to most potential inward investors. The early literature in this area (Czinkota and Kotabe, 2000; Lawrence, 1993a) has suggested that Keiretsu successfully deterred inward investment, either directly through their market dominance, or indirectly through their influence over government policy towards inward investment. However, the financial crisis in Asia and the prolonged recession in Japan has lead to an opening of the Japanese economy, and a loosening of Japanese firms’ closely knit business linkages and practices (Paprzycki and Fukao, 2008). Various long standing barriers to inward investment were removed, with keiretsu and business groups exposed to more intensive foreign competition (Chang, 2006). At the same time, the shift to overseas production begun by many Japanese MNEs in the 1980s has accelerated the so called 'hollowing out' process (Bailey, 2003; Bailey and Sugden, 2007; Sambharya and Banerji, 2006). As a result, the growth in outsourcing has created a demand crisis for keiretsu networks, weakening the traditional links between Japan's core assemblers and suppliers in vertically linked keiretsu (Cowling and Tomlinson, 2000). Furthermore, while various financial reforms ${ }^{\mathrm{i}}$ by the Japanese government were not directly targeted at keiretsu, they have nonetheless resulted in weakening ties among poorly performing keiretsu, thereby loosening up reciprocal shareholding among horizontal keiretsu 
members (Chang, 2006; Lin, 2005). Previously, Japanese firms often colluded with the bureaucracy to block foreign competitors, but foreign firms are now increasingly regarded as important allies in pressing for structural reform in Japan (Paprzycki and Fukao, 2008). This raises the following questions: Does the keiretsu inter-firm network influence the performance of inward FDI? If not, what industrtial structural properties will enhance the impact of keiretsu networks on foreign entry? To address these questions, we specifically examine the main and moderating effects of horizontal and vertical keiretsu on inward FDI.

Despite the prevalent view and anecdotal evidence that keiretsu affiliations deter foreign penetration in Japan, the empirical literature has by and large found no robust results to support this. The available statistical evidence on the role of keiretsu in influencing inward FDI is limited, mixed and in most cases contradictory. The evidence that does exist tends to be based on cross sectional analysis of highly aggregate data (Ito and Fukao, 2005; Lawrence, 1993a) and does not distinguish between vertically and horizontally linked keiretsu (Weinstein, 1996). This study therefore attempts to fill this gap by developing a model for inter-industry variations of inward FDI that incorporates networking of inter-keiretsu firms. We argue that the results depend on the networking process of keiretsu-affiliated firms, and that these firms constitute a conduit that channels the information diffusion and knowhow in the network when the level of ownership and location advantages are high and are therefore more likely to be welcoming to inward investors than may have been the case in the past. We test this hypothesis using panel data of Japanese manufacturing sectors from 1997-2003. Our approach controls for all unobservable sources of heterogeneity and endogeneity, therefore our findings also provide methodologically robust evidence.

\section{Inward FDI and Keiretsu}


The dominant paradigm in the analysis of (the lack of) inward investment into Japan has been based on analysis of the processes by which Japanese firms manage exchange relationships to reduce uncertainty and dependence. Evidence for this is found in the high levels of interlocking and overlapping business groups, employing complementary resources such as technology, marketing techniques, and distribution systems (Ghemawat and Khanna, 1998). Moreover, if such resources cannot be effectively exploited through the market or arm's length transactions, it would be efficient to integrate into groups. In principle, internal organization mitigates problems by allowing firms to better cope with both technological or product uncertainty, and market or commercial uncertainty, thereby leading to higher degrees of vertical integration in an industry (Wolter and Veloso, 2008). The most advantageous aspects of long-term relationships in vertical integration include the frequent mutual exchange of information, the ability to set up long-term inventory plans, and the reduction of search costs for finding new contractors (Mori, 1994). The incentive of information sharing and networking for quality improvement consequently lessens information asymmetries and can reduce contracting and monitoring costs (Nagaoka, Takeishi, and Noro, 2008). Vertical integration is preferred because tacit knowledge can be more easily appropriated by and transferred within a single firm, thereby preventing possible knowledge leakage (Wolter and Veloso, 2008). Opportunism is often controlled by self-enforcing safeguards such as relational trust and cross shareholding (stock ownership) between keiretsu members rather than legal contracts (Dyer, 1997). The cross shareholding in a Japanese business relationship is representative of a credible commitment that one firm has made to another firm (Lincoln and Gerlach, 2004). Within close knit keiretsu networks, member firms are often encouraged to cooperate and innovate through the sharing of technology and personnel exchanges (Cowling and Tomlinson, 2002). In sum, while the initial 'set-up' costs of developing 
relational trust or cross ownership are high in the short term relative to a legal contract, once such self enforcing safeguards are developed, transaction costs (i.e. search, contracting, monitoring, and enforcement costs) will decline over the long term. Thus, linkages across keiretsu firms are formed by means of commercial and personal ties, mutual board representation, cross equity shareholdings, joint business projects, and regular meetings of top executives. Nevertheless, whilst many firms in Japan have close links with a main bank and extensive ties with their suppliers and distributors, the formality, depth, and breadth of these ties, differ depending on whether the firm belongs to horizontal keiretsu, vertical keiretsu, or is an independent firm (Dewenter, Novaes, and Pettway, 2001). Horizontal keiretsu are groups of affiliated firms that span numerous and unrelated industries that are "centred" around a financial institution (i.e. a commercial bank). In contrast, vertical keiretsu are organised around a core firm (i.e. dominant manufacturing assemblers) with links along supply and distribution networks that generally operate within one industry (Sambharya and Banerji, 2006), where intermediate goods and services are supplied through an extensive use of vertical subcontracting arrangements (Coffey and Tomlinson, 2003). A core firm plays a leading role as an apex of a hierarchical system and a spider of an industrial web, controlling large production and technological value added activities through upstream and downstream supply chains (Ruigrok and Van Tulder, 1995). This type of hierarchical network of inter-firm organizational structure is prevalent in the consumer electronics (i.e. Toshiba, Panasonic) and the automotive industries (i.e. Toyota, Honda). Under rigorous internal control mechanism established, by for example, in Toyota's logistical chains, most manufactured inputs are produced by independent suppliers with guaranteed price, quality levels, and prompt delivery of strategic components (Ruigrok and Van Tulder, 1995). In particular, Japan's automobile industry has the largest number of vertical linkages sustaining highly dependent and cohesive 
relationships within the network of clusters (Coffey and Tomlinson, 2003). Toyota and other assemblers similarly developed industrial districts - clusters of a hierarchical supply system, which are comprised of agglomerations of their suppliers located within a range of $100 \mathrm{~km}$ of a central city, or so called "company castle town”, thereby allowing the assemblers to exercise their market power (Whittaker, 1997). Ultimately, the internal cohesion of vertical keiretsu network is much stronger than that of horizontal keiretsu network.

The keiretsu relationship creates informational and transactional efficiencies across the boundaries of member firms (Lin, 2005). These practices provide inherent cost of capital advantages and reduce the transaction costs for keiretsu member firms relative to those of outsiders. There are also possible efficiency gains through better information exchange, coordination, and monitoring that can outweigh the implicit costs of maintaining in-group preferences. Keiretsu affiliated firms also have privileged access to internal resources controlled by other members, thereby reducing resource constraints and the vulnerability of market fluctuations and stimulating firm growth.

In turn, this perspective along with more general cultural distance has provided the framework by which analysis based on transaction costs has explained the low levels of inward investment into Japan. The extant literature emphasizes that by performing the roles of internal markets, the keiretsu system serves as an efficient monitoring mechanism that can mitigate various agency problems (Kim, Hoskisson, and Wan, 2004). According to conventional industrial organisation theory, MNEs that engage in international production face a "liability of foreignness or newness" (Lincoln, Gerlach, and Takahashi, 1992), which arises from unfamiliarity with the host country's environment. They might be at a disadvantage when investing in locations where such a liability impedes their access to local resources in the host country (Garg and Delios, 2007). Further, stable inter-corporate equity 
holdings also act as a takeover defence by normalising group relationships, thereby making it difficult for foreign firms to enter Japan through acquisitions.

This dominant paradigm of the analysis of inward investment into Japan has found support from small sample survey and statistical evidence, which suggests that the presence of keiretsu networks can create informal barriers by facilitating collusion to restrict the market access of foreign firms (Czinkota and Kotabe, 2000; Lawrence, 1991; Lawrence, 1993b; Lawrence, 1993a). Lawrence (1993a) found that the share of both horizontal and vertical keiretsu firms in industry sales has a significant and negative effect on the market share of foreign-affiliated firms. Similarly, Weinstein (1996) finds a negative effect of horizontal keiretsu presence on inward FDI. However, the result is sensitive to different model specifications and is not robust enough to suggest that keiretsu presence deters foreign penetration. Nakamura et al.(1995) and Ito and Fukao (2005) do not find any evidence to support the collusion hypothesis raised originally in Lawrence (1993a), and therefore conclude that keiretsu presence is not a factor that influences the share of foreign participation. However, much of this literature is based on purely cross sectional analysis of broad industry groups, and is therefore unable to allow for unobservable heterogeneity across sectors, see for example (Ito and Fukao, 2005; Lawrence, 1993a; Nakamura, Fukao, and Shibuya, 1995).

Keiretsu networks can create informal barriers by facilitating collusion to restrict the market access of foreign firms (Lawrence 1991; Lawrence 1993a; Lawrence 1993b; Czinkota and Kotabe 2000). However, the econometric evidence to date is limited and contradictory. Weinstein and Yafeh (1995) provide evidence that it is fierce competition, not collusion, among keiretsu members that reduce entry of foreign and domestic firms into sectors where keiretsu are dominant. Further, developments in Keiretsu networking have led to greater links with global supply chains, and the use of Keiretsu in promoting cooperation between MNEs 
and indigenous firms (Belderbos and Carre, 2002; Belderbos and Sleuwaegen, 1996; Blonigen, Ellis, and Fausten, 2005). We therefore propose that there may be different channels through which keiretsu membership influences FDI decisions than those investigated in the literature. Prior studies also suffer from a significant shortcoming. They investigate only the main or direct effects between keiretsu presence and FDI, but do not fully explore where Keiretsu may fit into the wider theoretical analysis of FDI. It is important to recognize that ownership and location specific factors are embedded in keiretsu networks, and therefore that such considerations must inform empirical models. As discussed above, Keiretsu are conceptualised as networking and information sharing devices that may also be an attractive feature of a location for inward investors. Better analysis of this will improve understanding of business relations between keiretsu and foreign firms from an alternative theoretical perspective.

It is also informative to consider here the alternative modes of servicing a foreign market. Potential inward investors can of course eschew servicing the market through FDI, and export. One would expect that links between exporters and Keiretsu will be much weaker than links between inward investors and Keiretsu, such that any information sharing or beneficial effects to either party through location advantages will not be realised by exporters. On the other hand, the deterrence effects of Keiretsu are still present, and may deter potential exporters from entering the Japanese market.

\section{Network Perspectives on FDI}

Whilst a traditional view of FDI focuses on internalisation of firm specific assets, a network perspective on FDI highlights the exploitation of network resources for internationalisation 
(Chen, 2003; Chen, Chen, and Ku, 2004; Eng, 2007). Network resources are broadly categorised as follows: (1) inputs such as labour, capital, and raw materials, (2) intermediate product knowledge such as technology and operational know-how (3) markets, including distribution channels and buyer-supplier relationships (Guillen, 2000). The local presence is valuable to build trust and relationships in a foreign network, and a network may provide access to the flow of information content or distinctive resources that are not available in an investors' domestic market. Foreign MNEs can therefore utilise diverse and idiosyncratic network resources such as skilled labour, marketing, managerial expertise and technology during the process of internationalisation. In essence, basic resources such as unskilled labour and natural resources can be accessed through arm's length transaction from a home base without substantial international networking effort. By contrast, strategic network resources are inimitable and require considerable integration and coordination effort with a local network. If strategic assets are available in the host economy, then a foreign investor may develop R\&D facilities, supply/procure components and parts, and build distribution channels by resource sharing. Business relationships can be preserved, maintained, and enhanced through internationalisation of firms within a network by inducing inter-corporate and intracorporate linkages (Chen, Chen, and Ku, 2004). As such, FDI can be regarded as an effort by investors to develop linkages with local networks by establishing a presence in the foreign country. The network relationship established between firms through resource exchange and coordination therefore enables investors to gain economies of scale and scope (Eng, 2007). Assimilation and consolidation of leveraged external resources in a global setting are increasingly important since expanding into new product and international markets requires significant commitment of new resources (Kim, Hoskisson, and Wan, 2004). FDI in local linkages not only develops a platform for foreign based activities but may also 
generate positive spillovers to the host economy (Chen, Chen, and $\mathrm{Ku}, 2004)$. There is a large literature on the benefits of linkages between inward investors and domestic firms, but perhaps the better analogy is the relationship between inward investors and pre-existing clusters of activity. De Propris and Driffield (2006) for example show that mutual gains in productivity are made by inward investors and domestic firms where an inward investment links with a pre-existing cluster. This suggests that in the context of Keiretsu, the more local linkages that a foreign firm creates with keiretsu the greater the benefits to both the inward investor and host country firms. Such network relationships reduce transaction costs and facilitate knowledge sharing, in the form of product innovations. De Propris et al.(2005) demonstrates that a local industrial system characterised by a cluster of highly specialised domestic firms that possess competitive advantages induces FDI into both high and low techmanufacturing industries in Italy. Luo et al (2002) also point out that local networking, in the forms of linkages that foreign invested firms establish with domestic firms in the local market, greatly mitigate the liability of foreignness in China. Cluster participation reduces the relative unfamiliarity of foreign owned establishments operating in the foreign market by formal or informal knowledge exchange and transfer. Keiretsu share broadly similar features with cluster networks and Marshallian industrial districts in terms of networking and information sharing (Cowling and Tomlinson, 2000; Ozawa, 2003; Whittaker, 1997). The agglomeration effect of FDI is the result of vigorous local networking and linkages inducing new network partners. MNEs are regarded as an inter-organisational network embedded in a web of external networks consisting of buyers, suppliers, competitors, and regulators (Ghoshal and Bartlett, 1990). FDI involves a long-term business transaction where interactions take place not only between the headquarters in home base and their subsidiaries but also between subsidiaries and indigenous firms. Thus, when extensive transnational networking is 
undertaken from a home base without a local presence, building up new relationships in a foreign country can be costly (Chen, 2003).

Blonigen et al (2005) investigate the networking and information sharing effects that Keiretsu can have on the FDI decisions of Japanese firms. They find that horizontal keiretsu firms who hold President Club membership have a greater probability of engaging in FDI through mutual learning. This result can be extended to highlight the attractiveness of such sectors for inward investors, where such learning and networking effects can be a source of location advantages. Without networking with keiretsu members, foreign firms may find it difficult to obtain market information or to muster resources to make optimal decisions in expanding into the unfamiliar markets. Inter-firms networks have led to a rise in the recognition that networks contribute significantly to competitive, advantage, and that this includes interactions between inward investors and domestic firms. As Dyer and Hatch (2006) point out, firms are increasingly relying on network resources to gain access to diverse and complementary resources and knowledge that are not available internally. Various ownership and location tenets can notably influence the level of FDI activities, whilst the network architecture of keiretsu may also differentially interact with different dimensions of such sectoral attributes. Depending on the level and types of ownership and location attributes, inter firm network of keiretsu could have a greater or lesser relevance in FDI performance. For example, intensity of keiretsu affiliations with high level of ownership and location advantages facilitate the search and transfer of tacit and complex knowledge, therefore enabling foreign firms to combine with their existing knowledge sets, whilst preserving information transmission advantage from keiretsu clusters. The compositional quality of keiretsu networking and sectoral advantages enables a wide range of information to be exchanged and integrated efficiently, leading to greater multinational activity. We therefore posit that the entry of 
foreign firms in both horizontal and vertical keiretsu dominated sectors where diverse and rich information is available, enabling them to access a wide range of localized network resources, will be conditioned on the level of ownership and location specific attributes. In sum, this literature suggests the following hypotheses:

Firstly, that horizontal and vertical Keiretsu interact differently with FDI. Horizontal Keiretsu attract inward investors through the network effects, while vertical Keiretsu deter inward investors through entry barriers.

Secondly, that the interaction between keiretsu networks and ownership/location are important in explaining FDI. Consistent with the symmetrical nature of interactions, we expect that the effect of keiretsu dominance on FDI will be positive as the level of ownership and location advantages increases. Specifically, Keiretsu in sectors with significant scale economies may seek to ally their market power with inward investor's firm specific advantage.

However, a network of vertical Keiretsu may also form an entry barrier, preventing inward investment from forming linkages with domestic firms, and acquiring necessary inputs locally. The analysis of Girma (2002) or Driffield (2001) is informative here, in explaining links between entry barriers and entry decisions by inward investors. They show that where significant entry barriers have hitherto prevented entry, leading to high levels of concentration, only inward investors with sufficient ownership advantages to overcome these barriers are attracted to these sectors. This suggests that interactions between Keiretsu and entry barriers or location advantages are important for explaining inward investment.

In order to explore this further, we contrast the impact of Keiretsu on inward investment penetration, with import penetration. There are a number of reasons for doing this. Firstly, the FDI decision does not take place in isolation from alternatives, notably exporting from another location. Secondly, our underlying premise is that while Keiretsu do indeed form a 
barrier to entry in general, but that under certain circumstances network effects overcome this. Our third hypothesis then concerns the relationship between Keiretsu and imports. The network effects between importers and Keiretsu are unlikely to be significant, such that the entry barrier effect will dominate, and Keiretsu presence will be negatively related to import penetration into Japan.

\section{The Model and Data}

\section{The Model}

This model builds on the work of Girma (2002) which was developed from the entry literature. There are many studies of the determinants of entry, dating back to Orr (1974). Orr's work stimulated more formal models of entry, many of which are summarised in Geroski (1995), and Seigfreid and Evans (1994). This is then adapted to model FDI flows at the sectoral level, building on Driffield (2002) and Driffield and Munday (2000), which are both based on a standard empirical specification of Dunning's (1979) paradigm. The underlying assumption is that while a multinational's ability to develop and sustain competitive advantage would be positively related to the FDI decision, certain host country phenomena are also important. This was originally specified simply in terms of revealed comparative advantage and openness (Maskus and Webster, 1995; Milner and Pentecost, 1996). However, this has subsequently been extended, building on the entry literature of Rosenbaum and Lamort (1992), Shapiro and Khemani(1987) to incorporate host country entry conditions as determinants of inward investment, see for example Driffield (2001) or Neven and Siotis (1993). We therefore extend this model to include factors that are likely to influence FDI, such as a dominant set of indigenous inter-firm networks of keiretsu. We can operationalise this approach by expressing inward foreign investment as in the dynamic panel model below. Thus, FDI is a function of past FDI, and various industry characteristics, which serve as 
proxies for ownership and location advantage respectively.

$$
F D I_{i t}=\alpha+\beta_{0} F D I_{i, t-1}+\sum \beta_{k} X_{i t}+\gamma_{k} H K_{i t}+\delta_{k} V K_{i t}+\tau_{i}+\lambda_{t}+\varepsilon_{i t}
$$

where $F D I_{i t}$ is the level of inward FDI flows measured as the sales share accounted for by the foreign subsidiary in the corresponding sub-sector $i$ in year $t . F D I_{i t-1}$ is the level of FDI lagged by one year. $X_{i t}$ denotes the observable vector of regressors that explain inter-industry variations of foreign involvement in year $t$ to control for systematic differences in industry structure. HK and VK are measures of the intensity of financial centred horizontal keiretsu and the concentration ratio of manufacturing centred vertical keiretsu, respectively. Factors typically associated with the attraction of FDI, include advertising intensity (AD), capital labour intensity (KL), R\&D intensity (RD), and economies of scale (SCALE). These variables are typically associated with the ability of firms to generate ownership advantage, see for example Driffield (2002). Various location specific advantages and disadvantages include domestic market size (MSIZE), openness to trade (OPEN), revealed comparative advantage (RCA), and regulations on inward FDI (REG). $\tau_{j}$ is an industry dummy to capture industry effects and $\lambda_{t}$ a time dummy aimed at capturing shocks over time that are common to all firms. Finally, $\varepsilon_{i t}$ represents the error term. We estimate specifications testing our hypothesis with regard to whether the effects of keiretsu networks (VK or HK) in given sectors on inward FDI are moderated by a set of sectoral attributes. The rationale behind the inclusion of multiplicative terms is that keiretsu on their own may not be sufficient to influence the investment decision of foreign MNEs, but may have a moderating effect on FDI. Thus, it is possible that the keiretsu may not have an impact in isolation from other industry level phenomena. Accordingly, an interactive model is likely to be necessary to capture the 
conditional relationship, that is, the effects of keiretsu intensity on FDI vary according to the level and types of location and ownership specific tenets.

In order to allow for the fact that FDI is not the only mechanism for servicing a foreign market, we also consider the FDI model in the context of exporting by multinationals into $\underline{\text { Japan. We therefore set up a simultaneous panel data model, where we also specify a model }}$ examining the relationship between these control variables and imports into Japan.

$$
M_{i t}=\alpha+\beta_{0} M_{i, t-1}+\sum \eta_{k} Z_{i t}+\varphi_{k} H K_{i t}+\xi_{k} V K_{i t}+\gamma_{i}+v_{t}+u_{i t}
$$

where $M_{i t}$ is import penetration in industry $\mathrm{i}$ at time $\mathrm{t}, \mathrm{Z}$ is a subset of the $\mathrm{X}$ variables, discussed above, omitting open-ness and revealed comparative advantage, as they are tradebased measures.

\section{The data}

Our analysis covers 40 Japanese manufacturing sectors at the 'three-digit' level for the period 1997-2003. This is the maximum level of disaggregation for which the available data can be consistently matched over time. An appendix details the data sources used in our analysis. The main data set used in this study is based on the results of the Basic Survey of Japanese Business Structures and Activities from the Ministry of Economy, Trade and Industry (METI). This survey is one of the few official sources containing information on foreign affiliate firms in the Japanese economy and enables us to construct consistent panel data for the sectoral analysis.

\section{Measurement of variables}

Table 1 summarises the variables used in the empirical analysis along with the descriptive statistics. All monetary values are converted to real terms using the Corporate Goods Price 
Index (an equivalent to the PPI) to adjust for inflation.

[Table 1 about here]

\section{Dependent Variables}

Inward FDI is measured as sales share accounted for by foreign affiliated firms and is employed as our dependent variable. A large share of affiliate sales in the manufacturing sector in Japan is likely to consist of sales of services rather than of production ${ }^{\text {ii }}$ of goods per se. The sales measure is therefore well linked with not only production of goods but also with knowledge diffusion of superior product and marketing or distribution activities. Import penetration is similarly measured with industry level data on the ratio of imports to gross ouput.

\section{Keiretsu Network Variables}

Keiretsu variables are our primary interest and are meant to serve as proxies for information sharing and networking effects in respective sectors. Keiretsu membership is not clearly definable since there are no agreed criteria that classify a firm as a member. The criteria used to define the boundaries and to identify the members of keiretsu vary considerably across studies because of the informality of group membership. Following previous empirical studies (Kimura and Pugel 1995; Ueda and Sasaki 1998; Sakakibara and Serwin 2000; Nakamura 2002; Dewenter 2003; Blonigen et al. 2005b), horizontal keiretsu (HK) in this study are

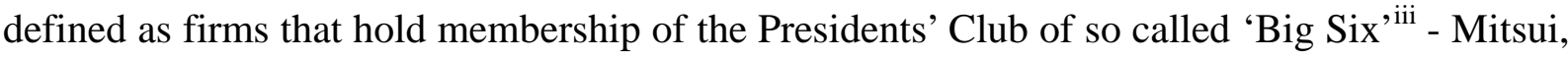
Mitsubishi, Sumitomo, Fuyo, Sanwa, and DKB. This is perhaps the narrowest and most restrictive definition of horizontal keiretsu, in which only the "core members" of each group are listed. The members ${ }^{\text {iv }}$ of Presidents' Clubs consist of representatives of the largest companies closely affiliated with each of the Six keiretsu, which are comprised of city banks, trust banks, insurance companies, general trading firms, and major manufacturing firms from 
unrelated industries. The city bank, or "main bank", of each of the Six often acts as a principle lender and a major shareholder to most of the affiliated non-financial members and provides not only long term credit finance but also potential market and business information. Executives of those club members participate once a month in the CEO meeting to share and exchange such information, and therefore Presidents' clubs take an essential role as a coordination mechanism (Blonigen, Ellis, and Fausten, 2005; Weinstein and Yafeh, 1995). This aims to gather resources benefiting the firm from other member firms represented by the CEOs as the strategic use of friendship networks. Horizontal keiretsu intensity is measured using the sales share accounted for by the member firms of the Presidents' Club. Keiretsu firms that did not appear in the data source for seven consecutive years due to bankruptcy or market exit are excluded from the sample.

Vertically organised keiretsu (VK) data are taken from Corporate Groupings in Japan, as detailed in table 1 . This focuses on the dominance of firms from the electric machinery and motor vehicles sectors. Sambharya and Banerji (2006) and Kimura and Pugel (1995) argue that electronics and motor vehicle manufacturers occupy the central and dominant positions among vertical keiretsu system. Resource and information flows are channelled from core firms at the hub of vertical keiretsu to various other members of the keiretsu. These industries need to extensively rely on knowledge-intensive collaboration in order to increase technological and economic returns and to better exploit their resources and competences.

\section{Estimation}

Equations (1) and (2) represent dynamic specifications of models explaining FDI and trade flows at the sectoral level, similar to that presented in Driffield (1999) or Girma (2002) The standard approach to this would be to employ a first difference model, in the spirit of Anderson and Hsiao (1982) and Arellano and Bond (1991). However, in this context there 
may be an additional complication. The decision to engage in FDI or exports does not exist in isolation, but rather one may consider that a firm seeking to enter the Japanese market directly has to decide between exporting and FDI. Thus, one has to allow for simultaneity between exporting and FDI. In estimation terms this presents a problem. One cannot simply estimate (1) and (2) using a standard three stage least squares estimator, as by construction the $\tau_{i}$ and $\gamma_{i}$ terms are correlated with each other, as well as with the lagged dependent variable in each case, by construction. One therefore has to remove the fixed effect through differencing. The first-differenced versions of the equations are therefore estimated simultaneously via iterated three stage least squares (FD-3SLS), following an approach developed by Cornwell et al (1992), and explained in more detail in Driffield and Girma (2004) ${ }^{\mathrm{v}}$.

\section{Results}

Table 2 sets out the results from the simultaneous equation estimation, with FDI and imports as the dependent variables. This is based on the 40 manufacturing sectors in our sample for the period 1997-2003.

[Table 2 about here]

We start by presenting the baseline model, and subsequrntly explore interactions between Keiretsu and the other explanatory variables. The baseline model is presented in column (1) with the full set of interaction terms included in the second model in column 2. For completeness, the exporting model (when estimated with the baseline model) is included in column 3. Our main focus is on the FDI models, though we discuss the export equation below. The control variables all have the expected signs. Consistent with Driffield and Munday (2000), the variables associated with the ability to generate ownership advantages, $R \& D$, advertising and capital intensity are positively associated with FDI, while measures of 
location advantages, such as market size and openness and regional agglomeration are also positive. The negative coefficients relate to the competitiveness of the domestic sector (RCA), and there is significant evidence that in the context of servicing the Japanese market, exporting and FDI are substitutes. The coefficient on the regulation variable (REG) is statistically significant, but has a counter intuitive positive sign. A possible explanation is that significant structural change took place in Japanese industry after the burst of the bubble economy. Such regulated sectors traditionally had very high institutional entry barriers, and as a result, the scope for domestic entry was limited. However, if institutional entry barriers have declined, international firms may now be looking to exploit their ownership advantages in Japan.

Turning to the main variables of interest, the Keiretsu variables, these results suggest that horizontal Keiretsu are positively associated with inward FDI. Such previous literature as there is in this does not find this result, but employs either standard fixed effects estimation (Weinstein, 1996), or OLS (Ito and Fukao, 2005; Lawrence, 1993a). This is rather limited, especially when one considers the inherent endogeneity and unobserved heterogeneity in models of FDI. Vertical Keiretsu by contrast do demonstrate a negative effect, but this is insignificant. These results highlight the importance of not merely focussing on Keiretsu, as much of the previous literature has done, but to differentiate between vertical Keiretsu and horizontal Keiretsu. In the same context, it is also informative that while horizontal Keiretsu are associated with an increase of FDI penetration, both forms are strongly associated with forming a barrier to import penetration. As such, as the previous literature has suggested, Keiretsu do indeed form a deterrent to foreign competition in Japan, but for the reasons discussed above, horizontal Keiretsu engage with, rather than compete with inward investors. 
Of potentially more interest is the model with the interaction terms. The coefficients on the Keiretsu terms are robust to the inclusion of the interaction terms, as are all the control variables. In the presence of significant interaction terms, the estimated coefficients for HK and VK in this model are simple or constituent effects rather than true main effects as the main effects lose meaning (Jaccard and Turrisi, 2003). An interaction takes place when the effect of one variable is significantly moderated by another variable. The "main effects" and "interaction effect" in a multiplicative model in no instance represent a constant effect of an independent variable on the dependent variable. The structure of keiretsu network conveys a positive effect on FDI flows, with realisation of scale economies being the major mitigating factor. Industries with significant scale economies, and Keiretsu, are more likely to attract inward investment. Distinctive network resources and capital developed by horizontal keiretsu advance the process of FDI by providing investing firms with essential market information to gain efficiencies and opportunities to establish local linkages to reduce the risks of undertaking FDI (Eng, 2007). Overall, the results suggest that market entry barriers are also circumvented through such local network resources. In terms of network accessibility, firms increasingly undertake FDI not only to exploit but also to augment their firm specific advantages or to acquire necessary strategic assets (i.e. technology, marketing, and managerial expertise) available in a foreign market (Dunning, 2000; Dunning, 1995). The underlying rational is that firm specific assets are developed through the capacity of investing firms to acquire and efficiently coordinate complementary resources possessed by other firms in a host country (Makino, Lau, and Yeh, 2002). A firm therefore chooses a particular investment location in which required strategic resources owned by indigenous firms are available to help develop firm specific advantages. Blonigen et al (2005) show that mutual learning effects in horizontal keiretsu are more significant than in vertical keiretsu. ${ }^{\mathrm{vi}}$. An extensive keiretsu 
network in unrelated business sectors provide heterogeneity of knowledge distributed across clusters acts as a vehicle for information and knowledge transfer, and takes an intermediary role in the relationship building between Japanese and foreign firms, therefore facilitating more investment. This can be extended to highlight the learning and networking effects as a valuable source of location advantages through interactions with Keiretsu. The positive moderating effects are also explained by our sample, which was derived from a "more open" period 1997-2003, where Japan started to be more welcoming toward inward FDI

Existing survey evidence (Czinkota and Kotabe, 2000) suggests that strong production and distribution networks, closely linked and captured by VK, deter foreign penetration. Girma (2002) or Driffield (2001) also show that where significant entry barriers have hitherto prevented entry, leading to high levels of concentration, only inward investors with sufficient ownership advantages to overcome these barriers are attracted to these sectors.

Model 2 highlights the importance of interaction between Keiretsu and certain location advantages that the sector possesses. R\&D intensive horizontal Keiretsu are less likely to attract inward investors, as firm specific advantage coupled with a strong network is less likely to either need investment from abroad to provide new technology, or be attractive for inward investors seeking to compete in new markets. In contrast, sectors with significant scale economies and Keiretsu are attractive to inward investors, seeking collaborations between new technology and efficient local production scale..

Finally, model three highlights the differences between Inward FDI and imports in terms of the explanatory variables. Of specific interest are the Keiretsu terms, and it is noticeable that Keiretsu deter entry by importers to a far greater extent than they do inward investors. This is also indicative that one of the principle reasons why Keiretsu do not deter inward investment to the extent that it might be imagined, is because of the additional networking or 
collaboration opportunities that inward investment presents. Clearly importers offer merely increased competition, and are deterred by Keiretsu.

\section{Conclusions}

The purpose of this paper is to empirically investigate the main and moderating effects of keiretsu networking on inward FDI across Japanese manufacturing sectors at the three-digit level during the period of 1997-2003 using a panel data set. Our results demonstrate that networking and information sharing effects of keiretsu and FDI are significantly moderated by ownership and location specific attributes and depend on the structure and type of linkage affiliations involved. However, there is no evidence of keiretsu presence deterring foreign entry, once one allows for persistence and endogeneity. Miwa and Ramseyer (2002) assert that the reason for conflicting results with regard to keiretsu impact is due to the changing nature of keiretsu boundaries and the multiplex nature of keiretsu ties. Whilst the diversified horizontal linked keiretsu combined with ownership and location advantages has positive moderating impacts on the foreign sales, the effect of vertical supply chains is mixed, placing some limitations on potential global network building. Our statistical results suggest that ownership factors associated with marketing skills, capital intensity and scale economies in the industrial sector dominated by horizontal keiretsu positively influence the sales activities of foreign firms. Furthermore, there is evidence that both horizontal and vertical keiretsu network facilitated by location advantages are likely to induce inward FDI. In contrast, increased capital and knowledge intensity with vertically organised keiretsu is negatively correlated with foreign sales penetration. This suggests that increased capitalisation and technological knowledge coupled with intra-industry supply chains in Japan acts as an entry barrier to inward FDI.

Finally, some important policy implications can be drawn from our empirical results. 
Japan's inward investment climate could be much improved by an increased understanding of the interactive relationship between industry attributes and network linkages of keiretsu affiliations. Liberalising and limiting market power and rigid control in certain areas, particularly in regards to the capital and knowledge intensive activities of the vertical supply chain is likely to be an effective policy for inducing foreign penetration. There is perhaps a need to monitor closely keiretsu activities so that affiliated group firms do not engage in exclusionary practices or exert monopoly control in the market. The current impression given in public discourse is that dealing with keiretsu following entry into the Japanese market is difficult and challenging. Clearly, the Japanese government needs to maximise its efforts to improve the overall image of Japan as an investment destination, and counter its perception as a market that remains relatively closed to foreign entrants. Effective public relations activities and dedicated policy measures are required to create a better perception of the investment climate faced by potential foreign investors. 
Table 1: Variables Definition, and Summary Statistics

\begin{tabular}{|c|c|c|c|c|}
\hline $\begin{array}{l}\text { Variable } \\
\text { Name }\end{array}$ & Definition & Description & Mean & S. D. \\
\hline FDI & $\begin{array}{l}\text { Foreign presence } \\
\text { measured by the } \\
\text { share of sales }\end{array}$ & $\begin{array}{l}\text { Sales of foreign firms / Total industry } \\
\text { sales in sectors }\end{array}$ & 0.044 & 0.079 \\
\hline $\mathrm{AD}$ & $\begin{array}{l}\text { Advertising } \\
\text { intensity }\end{array}$ & $\begin{array}{l}\text { Advertising expenditures / Total } \\
\text { industry sales }\end{array}$ & 19.469 & 19.716 \\
\hline KL & $\begin{array}{l}\text { Capital to labour } \\
\text { intensity }\end{array}$ & Tangible assets / Total employment & 0.022 & 0.022 \\
\hline $\mathrm{RD}$ & R\&D intensity & $\begin{array}{l}\text { R\&D expenditures / Total industry } \\
\text { sales }\end{array}$ & 0.009 & 0.010 \\
\hline REG & Regulation & $\begin{array}{l}\text { Weighted index of government } \\
\text { regulations in a given sector, ranging } \\
\text { between } 0 \text { and } 1.0 \text { for the weakest and } \\
1 \text { for strongest restrictions. }\end{array}$ & 0.260 & 0.358 \\
\hline MSIZE & $\begin{array}{l}\text { Domestic market } \\
\text { size }\end{array}$ & $\begin{array}{l}\text { Gross Output + Net Import (in } \\
\text { logarithm) }\end{array}$ & 16.152 & 0.952 \\
\hline SCALE & $\begin{array}{l}\text { Economies of } \\
\text { scale }\end{array}$ & $\begin{array}{l}\text { Average value added per establishment } \\
\text { accounting for the upper half of } \\
\text { industry value added divided by the } \\
\text { total value added in all establishments }\end{array}$ & 0.0010 & 0.0017 \\
\hline OPEN & Openness to trade & $\begin{array}{l}\text { (Real net exports }+ \text { Real net } \\
\text { imports)/Real gross output }\end{array}$ & 2.747 & 2.060 \\
\hline RCA & $\begin{array}{l}\text { Revealed industry } \\
\text { comparative } \\
\text { advantage }\end{array}$ & $\begin{array}{l}\text { (Real net exports - real net imports)/ } \\
\text { (real net exports + real net imports) }\end{array}$ & -0.160 & 0.522 \\
\hline IMPORT & Import & Real net imports/Real gross output & 1.579 & 1.655 \\
\hline PROFIT & $\begin{array}{l}\text { Industry } \\
\text { profitability }\end{array}$ & $\begin{array}{l}\text { (Real gross output - material -labour - } \\
\text { capital cost) / real gross output }\end{array}$ & -0.077 & 0.263 \\
\hline HK & $\begin{array}{l}\text { Intensity of } \\
\text { Horizontal } \\
\text { Keiretsu }\end{array}$ & $\begin{array}{l}\text { Share of sales by Horizontal Keiretsu } \\
\text { firms that belong to President Clubs } \\
\text { from the BIG SIX (Mitsui, Mitsubishi, } \\
\text { Sumitomo, Fuyo, Sanwa and DKB) } \\
\text { corporate groups. }\end{array}$ & 0.212 & 0.245 \\
\hline VK & $\begin{array}{l}\text { Top eight firm } \\
\text { concentration ratio } \\
\text { by Vertical } \\
\text { Keiretsu }\end{array}$ & $\begin{array}{l}\text { The proportion of industry sales } \\
\text { accounted for by sales to the largest } \\
\text { eight firms in Keiretsu Dominated } \\
\text { Sectors }\end{array}$ & 0.069 & 0.202 \\
\hline
\end{tabular}

To account for inflation, all monetary values (millions of Japanese yen) are adjusted to real terms using Corporate Goods Price Index $(2000=100)$. S.D. denotes standard deviation. 
Table 2: Three Stage Least Squares of FDI and Trade Models

FDI models

Trade model

\begin{tabular}{|c|c|c|c|c|c|c|}
\hline & \multicolumn{2}{|c|}{$(1)$} & \multicolumn{2}{|c|}{$(2)$} & \multicolumn{2}{|c|}{ (3) } \\
\hline & coefficient & $\mathrm{T}$ value & coefficient & $\mathrm{T}$ value & coefficient & $\mathrm{T}$ value \\
\hline Constant & -0.09 & -10.73 & -0.09 & -8.72 & -6.43 & -13.00 \\
\hline FDI (t-1) & 0.34 & 4.34 & 0.29 & 4.44 & & \\
\hline IMPORTS(t-1) & & & & & 0.71 & 4.78 \\
\hline $\mathrm{AD}$ & 0.85 & 2.42 & 0.69 & 2.22 & 0.57 & 4.21 \\
\hline $\mathrm{KL}$ & 0.002 & 10.73 & 0.002 & 11.57 & -0.18 & -0.16 \\
\hline SCALE & 0.52 & 1.39 & 0.54 & 1.32 & 0.50 & 4.08 \\
\hline $\mathrm{RD}$ & 0.89 & 11.20 & 0.85 & 10.15 & 0.19 & 3.36 \\
\hline REG & 0.02 & 2.59 & 0.03 & 2.66 & 0.58 & 4.08 \\
\hline MSIZE & 0.001 & 9.20 & 0.0005 & 9.89 & -0.33 & -6.80 \\
\hline OPEN & 0.01 & 3.67 & 0.01 & 3.83 & & \\
\hline RCA & -0.02 & -2.38 & -0.02 & -2.54 & & \\
\hline HK & 0.01 & 2.91 & 0.01 & 2.52 & -0.50 & -4.48 \\
\hline VK & -0.13 & 1.07 & -0.11 & 1.12 & -0.42 & -4.50 \\
\hline PROFIT & 0.002 & 0.15 & 0.002 & 0.13 & 0.15 & 1.45 \\
\hline IMPORTS & -0.73 & -7.96 & -0.61 & -8.27 & & \\
\hline FDI & & & & & -0.56 & 3.66 \\
\hline $\mathrm{HK}^{*} \mathrm{AD}$ & & & 0.45 & 2.51 & & \\
\hline $\mathrm{HK}^{*} \mathrm{KL}$ & & & 0.002 & 0.001 & & \\
\hline HK*SCALE & & & 0.70 & 3.30 & & \\
\hline $\mathrm{HK}^{*} \mathrm{RD}$ & & & -0.38 & 1.94 & & \\
\hline $\mathrm{HK}^{*} \mathrm{REG}$ & & & 0.01 & 0.07 & & \\
\hline HK*MSIZE & & & 0.09 & 0.02 & & \\
\hline HK*OPEN & & & 0.01 & 0.01 & & \\
\hline HK*RCA & & & 0.23 & 0.06 & & \\
\hline $\mathrm{VK}^{*} \mathrm{AD}$ & & & 0.08 & 0.13 & & \\
\hline $\mathrm{VK} * \mathrm{KL}$ & & & -0.0001 & 0.00005 & & \\
\hline VK*SCALE & & & 7.81 & 2.53 & & \\
\hline $\mathrm{VK} * \mathrm{RD}$ & & & -0.04 & 0.02 & & \\
\hline VK*REG & & & -0.0004 & 0.002 & & \\
\hline VK*MSIZE & & & 0.001 & 0.001 & & \\
\hline VK*OPEN & & & 0.001 & 0.0001 & & \\
\hline $\mathrm{VK} * \mathrm{RCA}$ & & & 0.01 & 0.002 & & \\
\hline Rsq (adj) & 0.78 & $.73)$ & 0.87( & $.74)$ & 0.67( & $.62)$ \\
\hline
\end{tabular}

\section{Appendix}




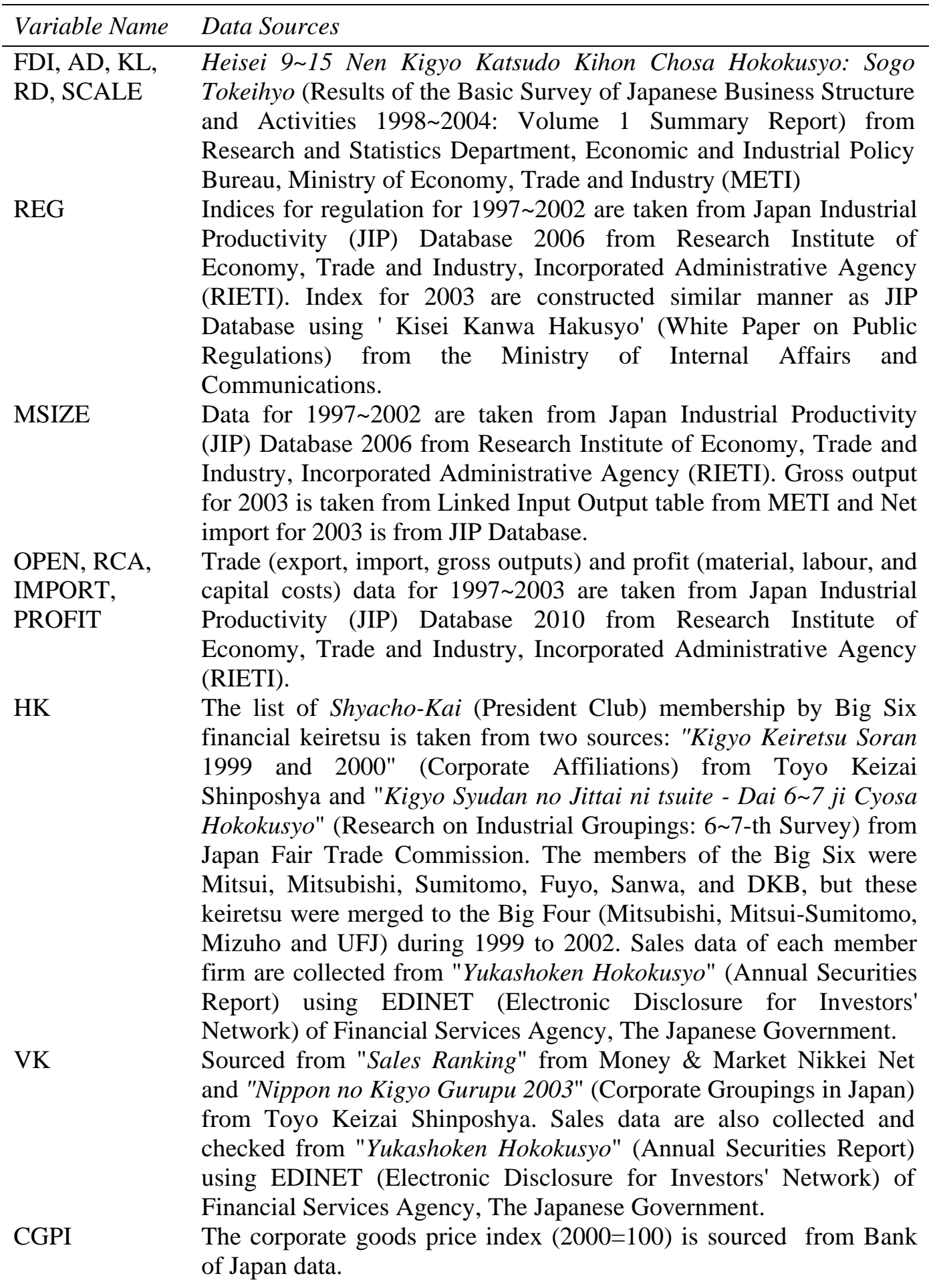




\section{References}

Arellano, M and Bond S. (1991). 'Some tests of specification for panel data: Monte Carlo evidence and application to employment equations'. Review of Economics Studies 58 , 277-297.

Arellano, M. and Bover, O. . (1995). Another look at the instrumental variable estimation of error-components models. Journal of Econometrics, 68(1), pp. 29-51.

Anderson T. and Hsiao C. (1982). 'Formulation and estimation of dynamic models using panel data'. Journal of Econometrics 18, 67-82.

Bailey, D. (2003). Explaining Japan's 'Hollowing Out': A case of government and strategic failure? Asia Pacific Business Review, 10(1), pp. 1-20.

Bailey, D. and Sugden, R. (2007). Kudoka, restructuring and possibilities for industrial policy in Japan.In D. Bailey, D. Coffey, \& P. Tomlinson, editors, Crisis or Recovery in Japan : State and Industrial Economy. Cheltenham: Edward Elgar

Baltagi B.H. (1995). Econometric Analysis of Panel Data. John Wiley \& Sons Limited.

Belderbos, R. and Carre, M. . (2002). The location of Japanese Investments in China: agglomeration effects, Keiretsu and firm heterogeneity. Journal of the Japanese and International Economies, 16(2), pp. 194-211.

Belderbos, R. and Sleuwaegen, L. . (1996). Japanese firms and the decision to invest abroad: business groups and regional core networks. Review of Economics and Statistics, 78(2), pp. 214-220.

Blonigen, B. A., Ellis, C. J., and Fausten, D. (2005). Industrial groupings and foreign direct investment. Journal of International Economics, 65(1), pp. 75-91.

Blundell, R. and Bond, S. (1998). Initial conditions and moment restrictions in dynamic panel data models Journal of Econometrics 87(1), pp. 115-143.

Buckley, P. J., Mirza, H. , and Sparkes, J. R. (1999). Recent developments in American and European direct investment in post-bubble Japan: Contrasting perspective.In R. Aggarwal, editor, Restructuring Japanese business for growth: Strategy, finance, management and marketing perspective. Norwell, MA.: Kluwer Academic.

Chang, S. J. (2006). Business groups in East Asia: Post-crisis restructuring and new growth. Asia Pacific Journal of Management, 23(4), pp. 407-417.

Chen, Tain-Jy. (2003). Network Resources for Internationalization: The Case of Taiwan's Electronics Firms. Journal of Management Studies, 40(5), pp. 1107 - 1130.

Chen, Tain-Jy., Chen, H., and Ku, Ying-Hua. (2004). Foreign direct investment and local linkages. Journal of International Business Studies, 35(4), pp. 320-333.

Coffey, D. and Tomlinson, P. (2003). Globalization, vertical relations, and the J-mode firm. Journal of Post Keynesian Economics, 26(1), pp. 117-144.

Cornwell, C, Schmidt, P and Wyhowski, D (1992). 'Simultaneous equation and panel data'. Journal of Econometrics 51, 151-181.

Cowling, K. and Tomlinson, P. R. (2000). The Japanese crisis - a case of strategic failure? The Economic Journal, 110(464), pp. 358-381.

Cowling, K. and Tomlinson, P. R. (2002). Revisiting the roots of Japan's economic stagnation: the role of the Japanese corporation. International Review of of Applied Economics, 16(4), pp. 373-390.

Czinkota, M. R. and Kotabe, M. (2000). Entering the Japanese Market: A Reassessment of Foreign Firms'Entry and Distribution Strategies Industrial Marketing Management, 29(6), pp. 483-491.

De Propris, L. and Driffield, N. L. (2006). The importance of clusters for spillovers from foreign direct investment and technology sourcing. Cambridge Journal of Economics 
30(2), pp. 277-291.

De Propris, L., Driffield, N. L., and Menghinello, S. (2005). Local Industrial Systems and the Location of FDI in Italy. International Journal of the Economics of Business, 12(1), pp. 105-121.

Dewenter, K. L., Novaes, W., and Pettway, R. H. (2001). Visibility versus Complexity in Business Groups: Evidence from Japanese Keiretsu. The Journal of Business, 74(1), pp. 79-100.

Driffield, N. L. (2002). Determinants of Inward Investment in the UK, a Panel Analysis. Applied Economics, 34(5), pp. 555-560.

Driffield, N. L. (2001). Inward investment, industry concentration and the speed of adjustment. Weltwirtschaftliches Archiv, 137(2), pp. 193-214.

Driffield, N. and Girma, S. (2003) 'Regional Foreign Direct Investment and Wage Spillovers: Plant Level Evidence From the U.K Electronics Industry.' Oxford Bulletin of Economics and Statistics, Vol. 65, (4) pp 453-474.

Driffield, N. L. and Munday, M. (2000). Industrial performance, agglomeration, and foreign manufacturing investment in the UK. Journal of International Business Studies, 31(1), pp. 21-37.

Dunning, J. H. (2000). The Eclectic Paradigm as an Envelope for Economic and Business Theories of MNE. International Business Review, 9, pp. 163-190.

Dunning, J. H. (1995). Reappraising the Eclectic Paradigm in an Age of Alliance Capitalism. Journal of International Business Studies, 26(3), pp. 461-491.

Dunning, J. H. and Lundan, S. M. (1997). Foreign direct investment in Japan and the United States: A comparative analysis. International Trade Journal, 11(2), pp. 187-220.

Dunning, J.H. (1979). Explaining patterns of international production: In defence of the eclectic theory. Oxford Bulletin of Economics and Statistics, 41(4), pp. 269-295.

Dyer, J. H. (1997). Effective Interfirm Collaboration: How Firms Minimize Transaction Costs and Maximize Transaction Value Strategic Management Journal, 18(7), pp. 535-556.

Dyer, J. H. and Hatch, N. W. (2006). Relation-specific capabilities and barriers to knowledge transfers: creating advantage through network relationships Strategic Management Journal, 27, pp. 701-719.

Eng, Teck-Yong. (2007). Relationship value of firms in alliance capitalism and implications for FDI. Journal of International Business Studies, 15(1), pp. 43-68.

Garg, M. and Delios, A. (2007). Survival of the foreign subsidiaries of TMNCs: The influence of business group affiliation. Journal of International Management, 13(3), pp. 278295.

Geroski, P. A. . (1995). What do we know about entry? International Journal of Industrial Organization, 13(4), pp. 421-440.

Ghemawat, P. and Khanna, T. . (1998). The Nature of Diversified Business Groups: A Research Design and Two Case Studies. The Journal of Industrial Economics, 46(1), pp. 35-61.

Ghoshal, S. and Bartlett, C. A. . (1990). The Multinational Corporation as an Interorganizational Network. Academy of Management Review, 15(4), pp. 603-625.

Girma, S. (2002). The process of European integration and the determinants of entry by NonEU multinationals in UK manufacturing. The Manchester School, 70(3), pp. 315-335.

Guillen, M. F. (2000). Business groups in emerging economies: a resource-based view. The Academy of Management Journal, 43(3), pp. 362-380.Holtz-Eakin, D., W.Newey and H.S. Rosen (1988) 'Estimating vector autoregressions with panel data'. Econometrica 56 , 1371-1375. 
Ito, K. and Fukao, K. (2005). Foreign direct investment and trade in Japan: An empirical analysis based on the establishment and enterprise census for 1996. Journal of the Japanese and International Economies, 19(3), pp. 414-455.

Jaccard, J. and Turrisi, R. (2003). Interaction Effects in Multiple Regression CA: Sage Publications

Kim, H., Hoskisson, R. E., and Wan, W. P. (2004). Power dependence, diversification strategy, and performance in keiretsu member firms. Strategic Management Journal, 25(7), pp. 613-636.

Kimura, Y. and Pugel, T. A. (1995). Keiretsu and Japanese direct investment in US manufacturing. Japan and the World Economy, 7(4), pp. 481-503.

Lawrence, R. Z. (1991). Efficient or Exclusionist? The import behaviour of Japanese corporate groups. Brookings Papers on Economic Activities, 1991(1), pp. 311-341.

Lawrence, R. Z. (1993b). Japan's different trade regime: an analysis with particular reference to Keiretsu. Journal of Economic Perspectives, 7(3), pp. 3-19.

Lawrence, R. Z. (1993a). Japan's low levels of inward investment: The role of inhibitions on acquisitions.In K. A. Froot, editor, Foreign direct investment. Chicago: The University of Chicago Press.

Lin, C. C. (2005). The transition the Japanese keiretsu in the changing economy. Journal of the Japanese and International Economics, 19(1), pp. 96-109.

Lincoln, J. R. , Gerlach, M. L., and Takahashi, P. (1992). Keiretsu Networks in the Japanese Economy: A Dyad Analysis of Intercorporate Ties. American Sociological Review, 57(5), pp. 561-585.

Lincoln, J. R. and Gerlach, M. L. . (2004). Japan's Network Economy: Structure, Persistence, and Change. Cambridge: Cambridge University Press.

Luo, Y., Shenkar, O., and Nyaw, M. K. . (2002). Mitigating liabilities of foreignness: defensive versus offensive approaches. Journal of International Management, 8(3), pp. 283-300.

Makino, S., Lau, Chung-Ming, and Yeh, Rhy-Song (2002). Asset-Exploitation versus AssetSeeking: Implications for Location Choice of Foreign Direct Investment from Newly Industrialized economies. Journal of International Business Studies, 33(3), pp. 403421.

Maskus, K.E. and Webster, A. (1995). Competitive advantage and the location of inward foreign direct investment: Evidence from the UK and South Korea The World Economy, 18(2), pp. 315-328.

Milner, C. and Pentecost, E. (1996). Locational advantage and US foreign direct investment in UK manufacturing. Applied Economics, 28(5), pp. 606-615.

Miwa, Y. and Ramseyer, J. M. . (2002). The fable of the keiretsu. Journal of Economics and Management Strategy 11(2), pp. 169-224.

Mori, K. (1994). An appropriate corporate and financial strategy for successfully investing in the Japanese market. Business Economics, 29(3), pp. 50-55.

Nagaoka, S., Takeishi, A., and Noro, Y. (2008). Determinants of firm boundaries: Empirical analysis of the Japanese auto industry from 1984 to 2002. Journal of the Japanese and International Economies, 22(2), pp. 187-206.

Nakamura, T. , Fukao, K. , and Shibuya, M. 1995. Tainichi Cyokusetsu Toshi wa Naze Sukunaika: Keiretsu matawa Kisei ga genin ka? (Why FDI into Japan is so small: Is it because of Keiretsu or Government Restrictions?). Tsusan Kenkyu Review 31, (MITI Research Institute Review) Ministry of International Trade and Industry.

Neven, D. and Siotis, G. . (1993). Foreign direct investment in the European Community - 
Some policy issues. Oxford Review of Economic Policy, 9(2), pp. 72-93.

Orr, D. (1974). The Determinants of Entry: A Study of Canadian Manufacturing Industries The Review of Economics and Statistics, 56(1), pp. 59-66.

Ozawa, T. (2003). Japan's Dual Industrial Structure as a Welfare System: The Lexus and the Olive Tree -- and the Vulture. Journal of Economic Issues 37(2), pp. 519-526.

Paprzycki, R. and Fukao, K. . (2008). Foreign Direct Investment in Japan: Multinationals' Role in Growth and Globalization. New York: Cambridge University Press.

Robinson, P. M. (1988) ‘Root-N consistent semiparametric regression'. Econometrica, 55, 931-954.

Rosenbaum, D.I. and Lamort, F. (1992). Entry, barriers, exit, and sunk costs - an analysis. Applied Economics, 24(3), pp. 297-304.

Ruigrok, W. and Van Tulder, R. (1995). The logic of international restructuring. London Routledge.

Sambharya, R. B. and Banerji, K. (2006). The effects of Keiretsu affiliation and resource dependencies on supplier firm performance in the Japanese automobile industry. Management International Review, 46(1), pp. 7-37.

Shapiro, D. and Khemani, R.S. (1987). The determinants of entry and exit reconsidered. International Journal of Industrial Organization, 5(1), pp. 15-26.

Siegfried, J.J. and Evans, L.B. (1994). Empirical studies of entry and exit : A survey of the evidence Review of Industrial Organization, 9(2), pp. 121-155.

Weinstein, D. E. (1996). Structural Impediments to Investment in Japan: What Have We Learned over the last 450 years.In M. Yoshitomi \& E. M. Graham, editors, Foreign Direct Investment in Japan. Cheltenham: Edward Elgar.

Weinstein, D. E. and Yafeh, Y. (1995). Japan's corporate groups: collusive or competitive? an empirical investigation of keiretsu behaviour. The Journal of Industrial Economics, 42(4), pp. 359-376.

Whittaker, D. H. (1997). Small Firms in the Japanese Economy. Cambridge: Cambridge University Press.

Wolter, C. and Veloso, F. M. (2008). The effects of innovation on vertical structure: perspectives on transactions costs and competences. Academy of Management Review, 33(3), pp. 586-605. 


\footnotetext{
${ }^{i}$ The financial system has generally been reformed to facilitate an environment of mergers and acquisitions in Japan. Changes in the accounting system have lead to a requirement to disclose the value of equity holdings at market value. This has resulted in massive sales of shares by bank centred keiretsu, and a stringent requirement for consolidation, making it difficult for firms to manage their earnings by allocating gains and losses among keiretsu group members.

ii Many foreign firms that are categorised as manufacturing companies are, in fact, associated with service and distribution activities rather than production per se.

iii Between 1999 and 2002, the Big Six were merged to the Big Four (Mitsubishi, Mitsui-Sumitomo, Mizuho and UFJ) following major restructuring of Japan's financial sector.

iv The membership is not mutually exclusive. For example, Hitachi is affiliated with the President Clubs of Fuyo, Sanwa, and DKB. We would note that some large manufacturing firms such as Honda, Sony, and Panasonic do not hold membership.

${ }^{\mathrm{V}}$ Our approach of estimating the system of dynamic panel equations is in the spirit of Holtz-Eakin et al (1988), thereby using lagged values as instruments to generate orthogonality conditions on differenced data.. Notice that in the linear context we are working with, the 3SLS estimator can be derived as a GMM estimator from the orthogonality conditions implied by the set of instrument (see Theorem 5 in Cornwell et al ,1992)

${ }^{v i}$ They find that horizontal keiretsu firms who hold President Club membership have a greater probability of engaging in FDI through mutual learning.
} 